\title{
DEN KULTURELLE PODNING AF DANSKE BYER - PERFORMATIV ARKITEKTUR OG MANGFOLDIG BYKULTUR
}

\section{Velferdsbyen under forandring}

Europas byer er ved at omdanne sig til scener for et byliv med kultur, underholdning og oplevelser som centrale omdrejningspunkter. Mange byer indretter sig således i disse år med nye pladser, strøggader og cafémiljøer som supplement til bykernernes shopping. I denne udvikling er oplevelse blevet nøglen til det moderne samfund og især til den moderne by. Oplevelse er blevet motoren i det, der da også kaldes "oplevelsesøkonomien” (Marling og Juul).

Vi er dermed vidne til et historisk skifte i den vestlige kulturs byer. De gamle industribyer er under afvikling; fabrikker lukker eller flytter bort, de gamle byhavne og deres havneliv er på samme måde på retur. Virksomheder, der tidligere lå som enklaver uden for byen, er nu ved at blive inddraget i det øvrige byrum, hvor de omdannes til kulturhavne, kontordomiciler eller kvarterer for velhavere. I takt hermed ændres hele bybilledet.

Den cyklende værftsarbejder i sit arbejdstøj med madkassen på bagagebæreren - det er bl.a. bybilleder, der er forsvundet. Væk er snart også de rygende skorstene og arbejderkulturens mødesteder: værtshuset, billardsalonen og de mange lokale fagforeningskontorer. Fabrikkernes store volumener erstattes af nye store kulturpladser, af "havnebade", byrum med klatrevægge, skøjtebaner og udendørs biografer. Fabriksfløjtens hvæsen afløses af lysshows og vandkunst med musik. De mørke og lukkede værtshuse mister deres kundeunderlag og lukker, mens nye designede cafeer og restauranter åbner dørene. Her kan gæsterne - til offentligt skue i de transparente og oplyste omgivelser - nyde den kunstnerisk arrangerede mad i en samlet sanseoplevelse. Samtidig danner de centrale bydele kulisser for stadig flere events.

Det moderne byliv er mere end blot en simpel reproduktion af arbejdskraften. Der er krav om mere og andet end lys, luft, rekreation og tilgængelighed til velfærdsgoder. Sanser og følelser skal også pirres.

Vi bruger et stigende antal timer og flere penge, og vi kører et stigende antal kilometer på vores "FUN", konstaterer Tracy Metz og fortsætter: "Holland har aldrig før haft så mange events og festivaler, så mange shopping Sundays, parties, 


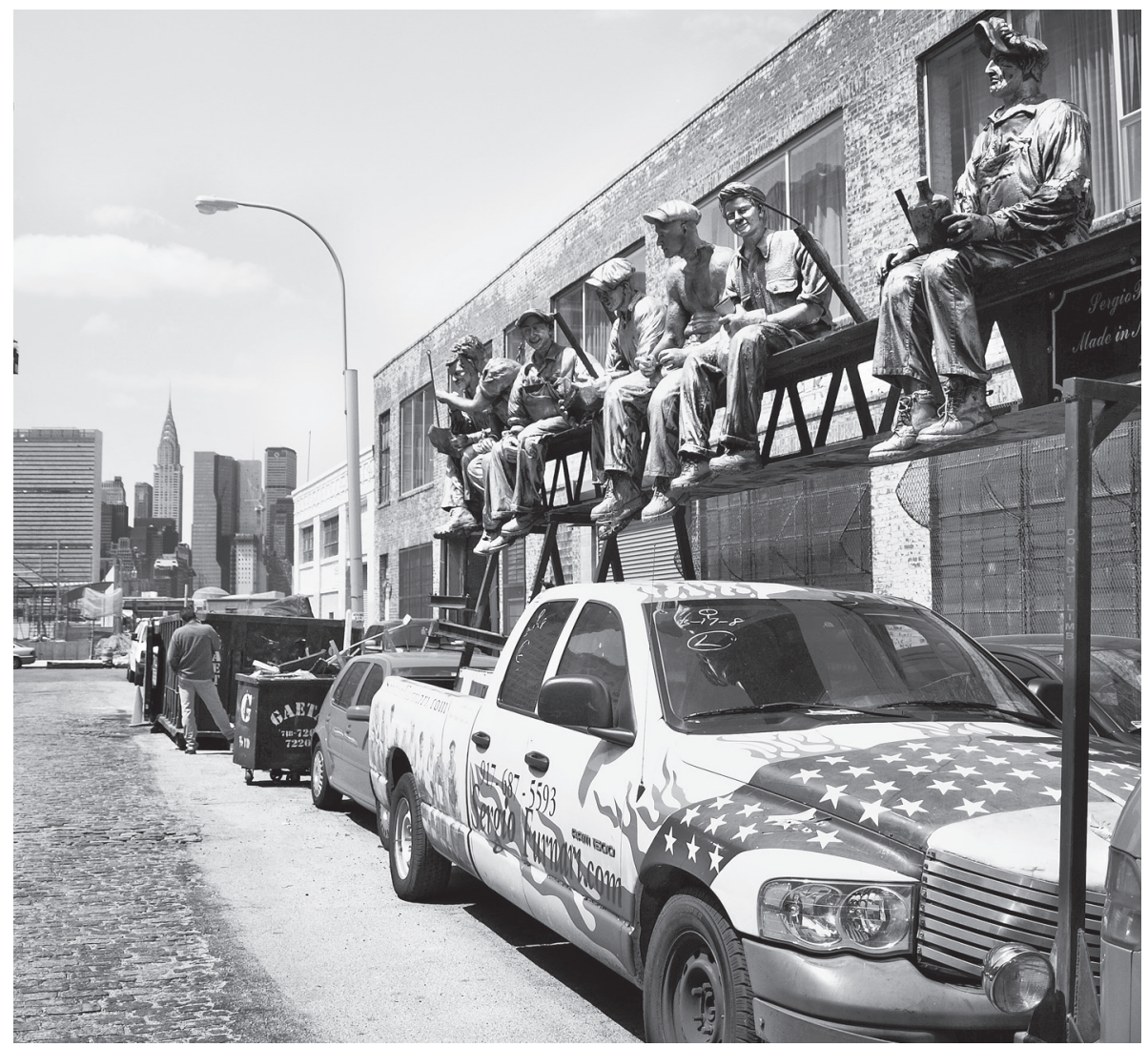

Figur I: New York: fra bygningsarbejdere til bygningsudsmykning.

(Foto: Gitte Marling)

skøjtebaner, stadiums, MEGA-biografer, børne-paradiser eller sommerhuse, ferielejligheder mv.” (8) (Egen oversættelse).

Hun påviser, hvorledes virkningen af alle disse aktiviteter bliver mere og mere synlige i vores omgivelser i byen og på landet. Metz argumenterer desuden for, at vores sociale identitet i dag ikke kun bestemmes ud fra vores job og uddannelse eller besiddelser; men i høj grad også ud fra den måde hvorpå vi bruger vores fritid. Vi skal som personer selv "performe". Det bliver i den forbindelse vigtigt for den enkelte at blive set på de rigtige steder og ved de "hotte" begivenheder. Ud over de fysiske og arkitektoniske forandringer af byen påpeger Metz endelig, hvordan der skrues op for det kulturelle aktivitetsniveau.

“'Leisure' er langt mere end blot den tid, du kan bruge, som du selv synes bedst. "Leisure" har udviklet sig til at blive en overgribende "culture of fun" med en enorm økonomiske betydning” (8) (Egen oversættelse).

Ser vi på udviklingen i en dansk sammenhæng, så bekræfter en spørgeskema- 


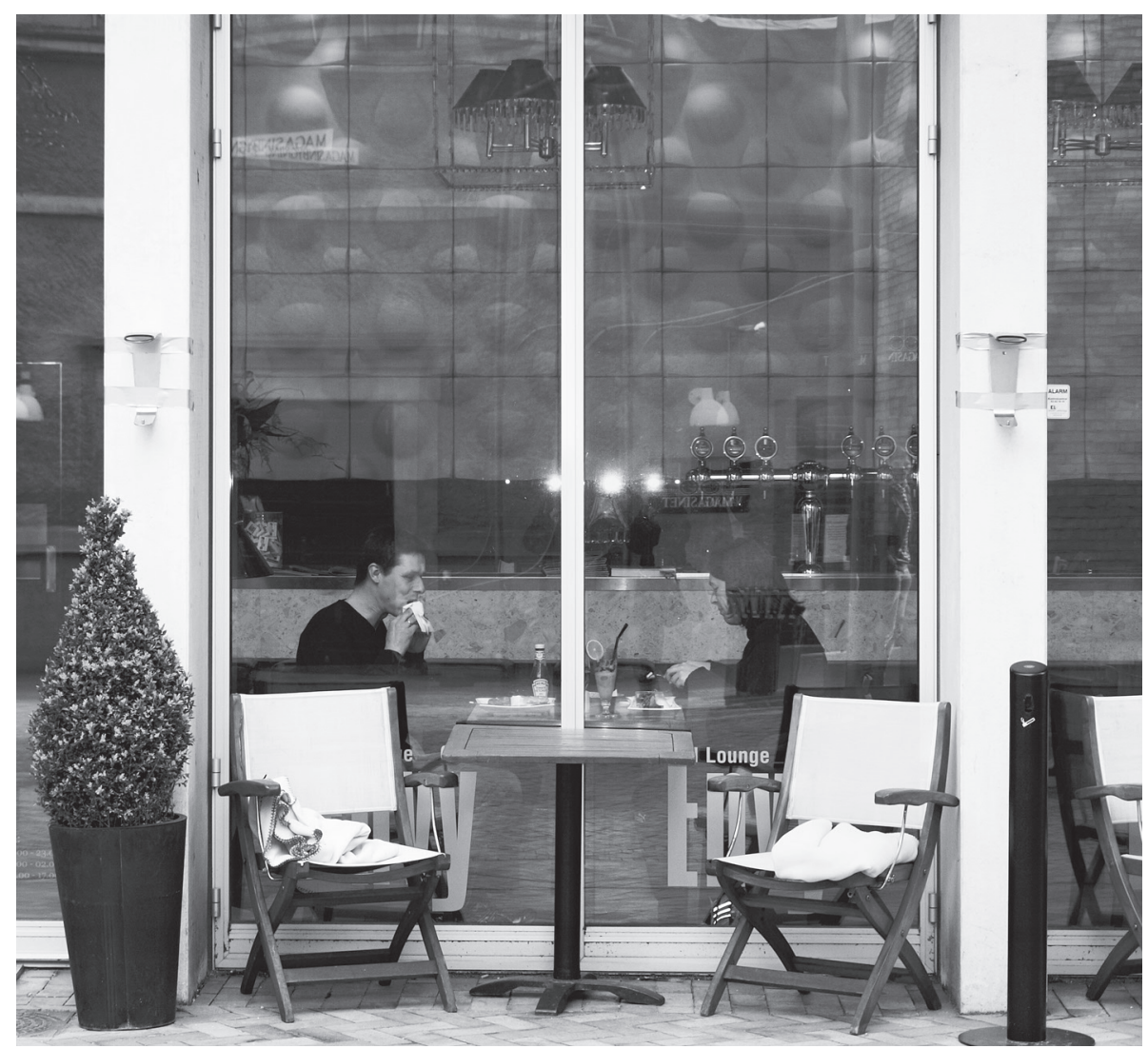

Figur 2: Det kulturelle område i Odense: Cafémiljø ved Brandts Klædefabrik.

(Foto: Gitte Marling)

undersøgelse af danske kommuners kulturelle satsning en parallel udvikling. $62 \%$ af alle danske kommuner indgik i undersøgelsen, og blandt disse har $64 \%$ etableret forskellige former for nye større kulturprojekter i løbet af de seneste ti år. Der er først og fremmest tale om nye teatre, spillesteder, biblioteker og biografer, udstillinger mv., der sammensættes i nye hybride kombinationer. Det giver et blandet kulturelt tilbud, og det betyder, at forskellige befolkningsgrupper føres sammen (Marling, Kiib og Jensen, Experience City. DK).

99 \% af kommunerne afholder hvert år en eller flere større kulturelle events i form af festivaler, karnevaler, parader, koncerter, arrangementer med midlertidig kunst og digte i det offentlige rum eller tilsvarende. Ifølge kommunernes egne kommentarer arbejdes der bevidst eller ubevidst med to strategier: en indadvendt og en udadvendt. Hvor det indadtil handler om at bruge de kulturelle events til at skabe sammenhængskraft, selvidentitet og lokal forankring, så handler det udadtil om "at komme på landkortet”, som det hedder, dvs. at gøre opmærksom på sig 
selv som en by med særlige kulturelle kvaliteter. Den indadvendte strategi bygger på lokale traditioner og fester. Den appellerer til en bred målgruppe. Den udadvendte strategi kræver en bestandig fokusering på originalitet og kvalitet. De byer, der forfølger denne strategi, søger gennem højt profilerede events at brande sig og positionere sig selv $\mathrm{i}$ forhold til landets andre byer (Marling, Kiib og Jensen, Experience City. DK).

I de største byer, hvor der er mange arrangementer og begivenheder året rundt, opstår der af og til konflikter, fordi hverdagslivet i de centrale bydele generes af bl.a. støj og affald, der flyder på pladser og i gader. Arrangementerne skaber trængsel og får kollektive trafiksystemer til at bryde sammen. Kritikken af udviklingen er også, at der sker en såkaldt "tivolisering" eller "disneyfisering" af bymiljøet (Marling og Zerlang).

Ud fra lidt forskellige tilgange har en række byteoretikere i de seneste år beskæftiget sig med at sætte benævnelse på den udvikling, der kan observeres. Michael Sorkin omtaler den moderne by som en by, der har udviklet sig til en stor temapark, hvor de almindelige offentlige byrum er forsvundet, og hvor demokratiet er sat ud af kraft. Der er ingen demonstrationer i Disneyland, påpeger han, og henviser til, at alt byliv i amerikanske byer foregår i privatejede rum, hvortil der er offentlig adgang, hvis ellers f.eks. tøjvalg og opførsel er i overensstemmelse med den fastsatte kodeks (Sorkin).

Tracy Metz har som omtalt fokus på oplevelsesøkonomiens pres på hverdagslivet og bymiljøet. Hun italesætter den moderne by som "Fun City" (Metz); mens Nigel Coats taler om "Ecstacity" (Coats). Benævnelserne er forskellige, men fokus ligger stort set på de vilde eller de negative konsekvenser af oplevelsesøkonomiens pres på bykulturen.

For at vores byer ikke skal udvikle sig til rene underholdningsmaskiner, er der således god grund til at diskutere, hvilke kvalitetskrav oplevelsesøkonomiens fremmarch bør mødes med. Udviklingen af bykulturen er selvsagt ikke kun et spørgsmål om at etablere stribevis af kulturprojekter. Der må stilles krav om, at omstillingen fra industriby til oplevelsesby sker på et grundlag, hvor udfordringer, eksperimenter, refleksion og elementer af læring bliver en del af grundlaget - alle byer, og ikke mindst de danske velfærdsbyer må arbejde for at fastholde deres images' af at være åbne, demokratiske og socialt mangfoldige byer, med tilbud og plads til alle, unge, gamle, forskellige livsstile og kulturer (Marling).

\section{"Experience City" i stedet for oplevelsesby}

På dansk anvendes begrebet "oplevelsesbyen". Begrebet har klare referencer til begreberne "oplevelsesøkonomi” og "oplevelsesdesign”. Forskellige produkter eller serviceydelser tilsættes et par dråber oplevelse, hvorefter de kan sælges til en merpris. Det er en gammelkendt sandhed, at forbrugerne er villige til at betale en høj pris for en kop kaffe, der serveres i en designet kop og i et usædvanligt og oplevel- 
sesrigt miljø (Pine og Gilmore). Benævnelsen "oplevelse” er imidlertid ikke så bred og nuanceret som det tilsvarende engelske begreb "experience". "Experience” dækker over at undersøge, udforske, teste, opdage, erfare og opleve - og efter "the experience” er man blevet klogere, har fået erfaring, ny viden og måske nye kompetencer ...

The experience city er derfor også byen, hvor man kan blive rigere på erfaring, oplevelser og læring. The experience city er mere end blot en forlystelsespark. Derfor stiller The experience city også krav til arkitekturen, til design af rum og til det kulturelle indhold i events og arrangementer (Marling, Jensen og Kiib, "The Experience City").

I det følgende gennemgås et par eksempler på kulturprojekter, der på forskellig vis kommer disse krav om kvalitet i møde.

\section{Århus Festuge - kunsten og kulturen som "dialog manifest"}

Først et eksempel på, hvorledes noget så midlertidigt som en årlig kulturfestival kan udfordre bylivet og tilbyde et nyt blik på de muligheder og potentialer for social og kulturel læring, som byen rummer. Fortællingen handler om Århus Festuge, der finder sted hvert år i den første uge i september måned. Omsætningen på ca. I7 mio. kr., vidner om, at der er tale om et stort anlagt program.

Formålet med Århus Festuge har siden starten i 1965 været, at kunsten og kulturen skulle bringes i fokus og bredes ud til borgerne. Derfor er Århus Festuge mange ting, mange kunstarter og udtryksformer. Programmet udtrykker bl.a. direktørens valg af tema og måde at belyse det på. Det udtrykker dog i lige så høj grad, hvad der bobler og spirer i byens forskellige kunstnermiljøer.

Århus Festuge er med sine godt 500 forskellige arrangementer et markant "brand" for Århus. Det er ugen, hvor mange århusianere deltager i det store udbud af aktiviteter og underholdning, der bydes på.

Den nuværende direktør for Festugen, Jens Folmer Jepsen, lægger vægt på at tilbyde en mangfoldighed af oplevelser, gerne enestående, på forkant og uventede. I forbindelse med Festugen udvikles nye produkter og koncepter i et samarbejde mellem erhvervslivet og kunstnere og mellem forskellige institutioner, kunstnere og andre deltagere. Med temaet "åben by" satte han i 2008 fokus på byens kulturværdier og ukendte potentialer. Formålet var at åbne borgernes øjne for byens rumlige potentialer og for dens mangfoldighed af hverdagskulturer. I 2008 fandt en del af festugearrangementerne således sted i byens offentlige rum. Et af de projekter i byens rum, der skabte en del omtale i medierne, var en installation med navnet "Opera" - der var en "Christiania-agtig" træbebyggelse med boder, scener, hyggekroge mv. En konstruktion med platforme i op til otte meters højde. Konstruktionen var effektbelyst om aftenen, hvilket gav et stemningsfyldt miljø. Operaen trak mange - og måske mest unge til sig og etablerede i løbet af ugen et sydende og levende musiksted. Samtidig med at projektet etablerede et midlertidigt byrum og 

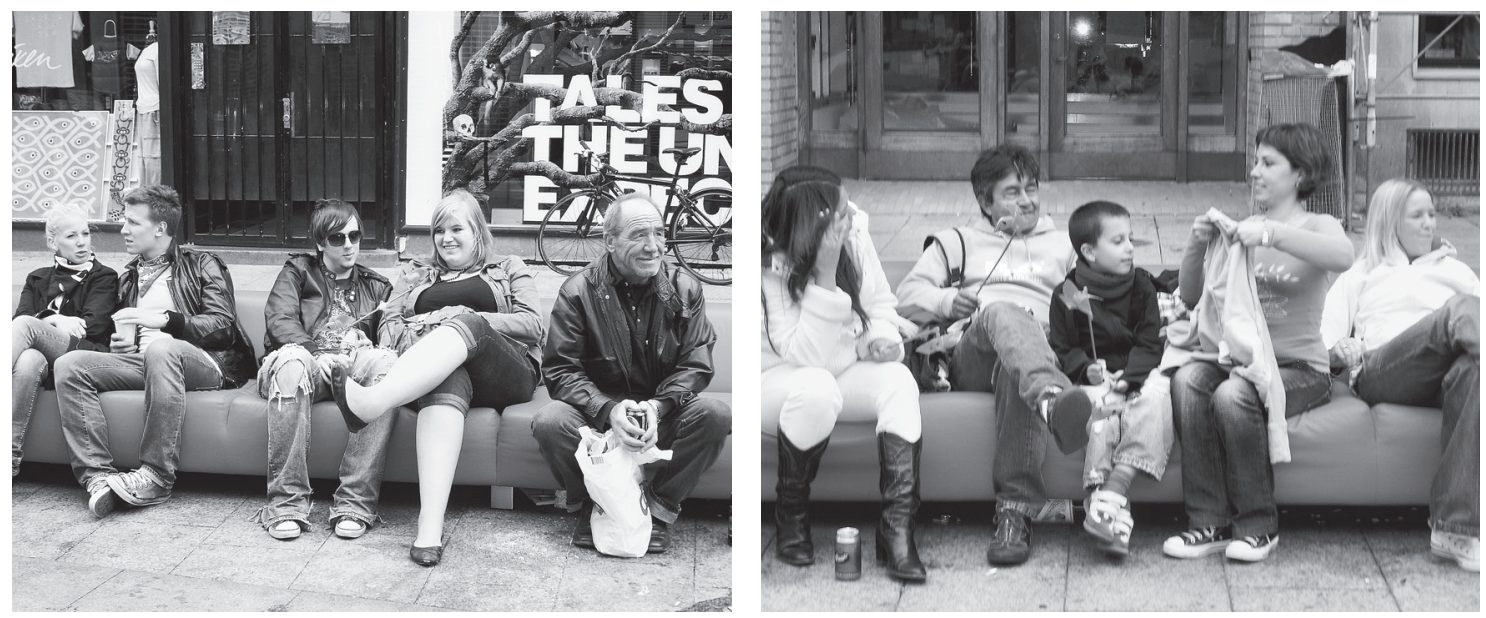

domæne for de unge, skabte Operaen også opmærksomhed om et hidtil overset hjørne af Museumsparken ned til Århus Å. Efter festugen blev lyset og lyden slukket og installationen taget ned og pakket sammen. Det var en enestående performance, som påpegede behov og potentialer $\mathrm{i}$ byen.

Den "røde rute" og den "blå rute" er to andre projekter, der bør nævnes i forbindelse med festivalens fokus på byen og byens offentlige mødesteder. Den røde rute blev lanceret i 2007 og forbedret i 2008. Den var arrangeret i samarbejde med en lang række kulturinstitutioner, gallerier, kunstnere, arkitektfirmaer, designfirmaer osv. Ideen var at etablere en rute gennem byen som et tilbud til byens borgere om at opleve byen fra andre og måske ukendte vinkler. Ruten gik som en rød tråd gennem byen og festugeprogrammet. Den udstillede byens mangfoldighed, kvaliteter og potentialer, både menneskeligt og arkitektonisk. Ved at følge ruten blev man ledt frem til forskellige steder inklusive baggårde, hvor kunstnere arbejdede. Rådhuset var lyst op med rødt, og Klostertorv var klædt i rødt. Højdepunktet var verdens længste sofa på Lille Torv.

På dette torv, hvor folk normalt haster forbi i mangel af siddepladser, hvilede i festugen alle slags trætte fødder og deres ejermænd og -kvinder side om side. Den lange røde sofa var populær. Her kunne man observere noget så ualmindeligt som øldrikkende mænd side om side med børnefamilier, pensionister og unge teenagere. Folk i alle farver og størrelser indtog Lille Torv. De så tilmed tydeligvis ud til at nyde både situationen og hinandens selskab. Festugesekretariatet kalder selv projektet for et vellykket "dialog manifest" (Marling, Kiib, og Jensen, Experience City. $D K)$.

Den blå rute relaterede sig direkte til temaet “åben by og åbent landskab”. Den blå rute inviterede til en cykeltur med familien. Igen var ideen at åbne de lukkede dele af byen op. Hver dag blev der åbnet et nyt sted. Fængslet, den store private containerterminal, fængselsgården, borgmesterkontoret, Bogtårnet på Statsbiblio- 

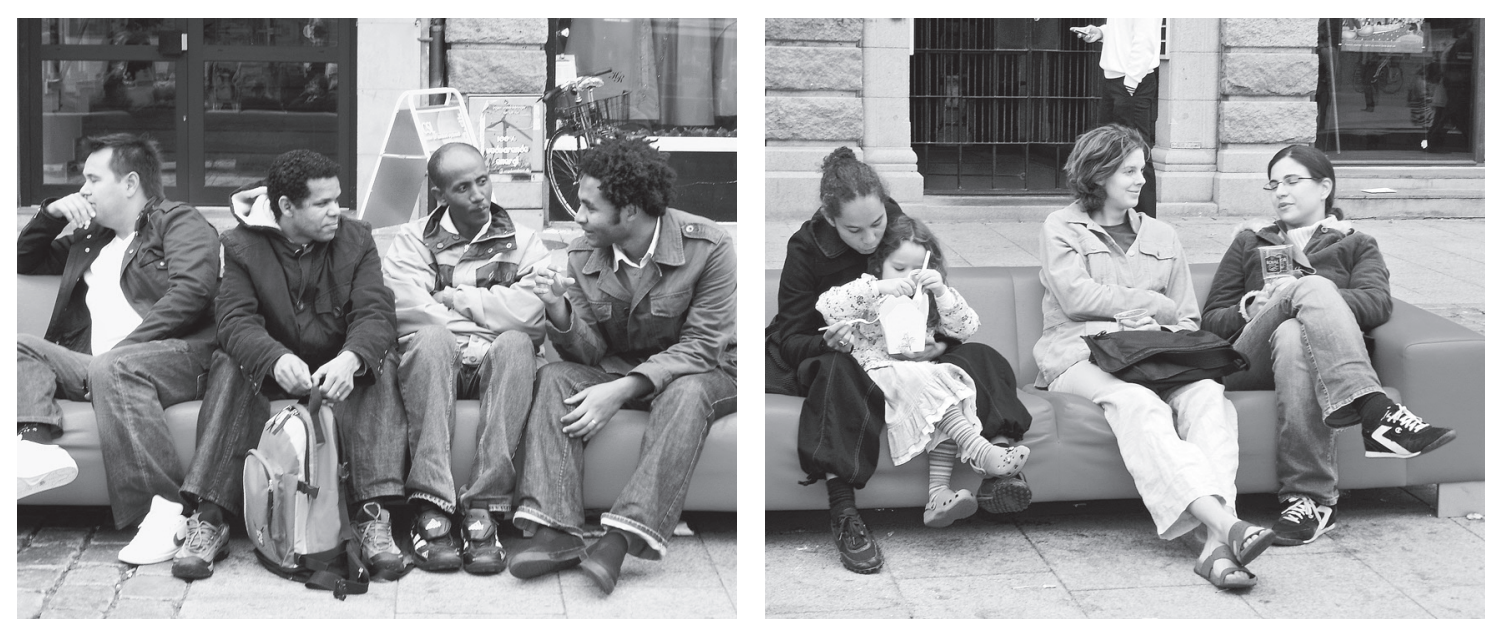

Figur 3-6: Århus Festuge: verdens længste sofa.

(Foto: Gitte Marling)

teket og en opgang i Gellerupparken, hvor der bor en del "nydanske" familier. Formålet var også her at lære noget nyt om byen og dens mange hverdagskulturer.

På Lille Torv gav den lange røde sofa anledning til, at mange stoppede op. Satte sig eller betragtede dem, der satte sig. Dette byrum, hvor folk normalt blot hastede forbi, forandrede sig i løbet af ugen fra at være, hvad byteoretikeren Michael Waltzer kalder for "single minded" byrum. Det vil sige et rum med en enkel og afgrænset funktion - i dette tilfælde et gennemgangsrum - til at være et "open minded" byrum, hvor der var mulighed for at opholde sig på flere forskellige måder på en og samme tid (Waltzer 32I).

De mange forskellige rum og steder på den blå og røde rute skabte et socialt og kulturelt møde mellem grupper af borgere med forskellig kultur og social væren. Muligheden var dermed til stede for etableringen af, hvad Martin Haajer og Arnold Reijndorp kalder "public domains”, dvs. offentlige eller private rum med offentlig tilgængelighed, hvor livsstilsgrupper med forskellig baggrund oplever, at der sker en social og kulturel læring eller udveksling (Haajer og Reijndorp).

Enkelte eksempler fra det mangfoldige program er nævnt her for at illustrere, at Århus Festuge er andet og mere end blot fest og underholdning. Festugen markerer sig med et væld af kulturdialoger, politiske debatter og inviterer til kulturel interaktion og til åbning af nye perspektiver. Med deres midlertidighed udgør de mange små og store kulturprojekter ikke nogen større trussel mod hverdagslivet i byen, og måske netop derfor synes tolerancen at være større over for eksperimenter og nye udtryk. Det giver et relativt stort spillerum, både til at vise nye veje i brugen af byens rum og til rumlig og arkitektonisk udvikling. Det betyder imidlertid ikke, at festugen er uden for journalisters og nyhedsmagasinernes søgelys. 
Tværtimod er pressen overordentlig opmærksom på alle nye initiativer, potentielle konflikter mv., hvilket er med til at holde hele arrangementet levende år efter år.

\section{Bazar Fyn - et public domain med kulturel udveksling via markedshandel}

At handel gennem tiderne har skabt social og kulturel udveksling er ikke noget nyt. Gennem årtusinder har handelsmænd rejst gennem landskaber af forskellige kulturer. De medbragte fremmede dufte, produkter, kunst mv. og profiterede økonomisk på forskelligheden. "Købmand", developer og direktør Olav de Linde mener, at netop handel er en god måde at skabe kulturel integration mellem "nydanskere" og "gammeldanskere". Hans udgangspunkt er integration, der ikke ensidigt er baseret på, at de nye borgere skal underkaste sig dansk kultur, men derimod er baseret på gensidig social og kulturel udveksling.

Med Bazar Fyn i Odense har han iværksat et kulturprojekt med dette formål for øje. Bazar Fyn åbnede i 2007. Bazaren har indrettet sig med mere end 65 forskellige forretninger og restaurationer på $7.000 \mathrm{~m}^{2}$ i Thrige-Titans gamle fabriksområde.

Erfaringsmæssigt er Bazar Fyn baseret på Bazar Vest, der er et af Olav de Lindes tidligere projekter i Gellerup ved Århus. Olav de Linde forklarer, at han i Bazar Vest var så meget sammen med stadeholderne, at han ved selvsyn kunne konstatere, hvor meget de lærte, og hvor meget de arbejdede, fordi forretningen eller cafeen var hele deres liv. De Linde er overbevist om, at handel er den bedste måde at integrere dem på. "De lærer, hvad sukker koster, hvordan man køber ind eller passer et arbejde. Husk på at mange af dem ikke har arbejdet i mange år. De har boet i flygtningelejre, og deres forældre har også boet i flygtningelejre. Man må huske på, hvad de er oppe imod, når de skal starte på sådant et projekt”, forklarer Olav de Linde (Marling, Kiib og Jensen, Experience City. DK 296).

Olav de Linde har i planlægningsfasen arbejdet tæt sammen med By- og Kulturforvaltningen, Odense Kommune. Visionen var at placere basaren inde i byen, således at den kunne fungere som en dynamo for beskæftigelse og integration af indvandrermiljøer, men samtidig være med til at tydeliggøre Odense som en kulturelt mangfoldig by.

Det sidste lægger Jan Boye, der på det tidspunkt var borgmester i Odense, stor vægt på. Han bakker op om projektet og siger, at Odense Kommune ser Bazar Fyn som et spændende og markant initiativ i Odense. Han pointerer, at basarens potentiale som indfaldsvinkel til arbejdsmarkedet for mange borgere med anden etnisk baggrund blot er ét vigtigt aspekt. Et andet er basarens multikulturelle og moderne profil, som kan være med til at brande byen som et fremsynet og farverigt sted i Danmark ("H.K.H. Prins Joachim indvier Bazar Fyn").

Initiativtagerne har en klar idé om, at det handler om at forstå den kultur, som disse mennesker bringer med sig og bruge den i en forretningsmæssig sammenhæng. Påstanden er, at for mange nydanskere er "markedspladsen” en slags "of- 


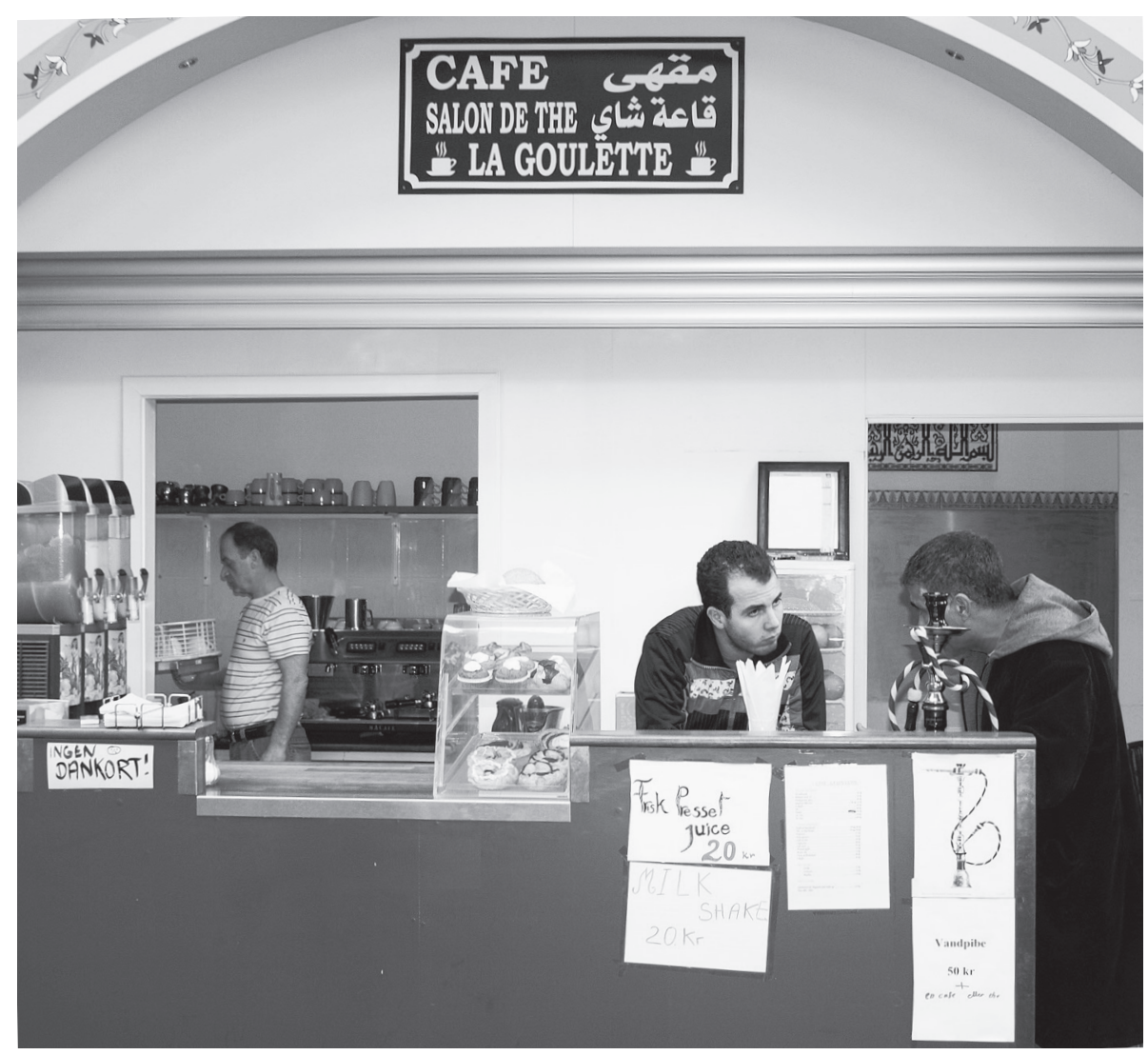

Figur 7: “Den offentlige dagligstue” på Bazar Fyn.

(Foto: Gitte Marling)

fentlig dagligstue”. Her kan man mødes, komme i dialog og måske vende sine tanker om offentlige spørgsmål. Kulturforståelse og markedstænkning kobles i dette felt.

Basaren rummer madboder, restauranter og et lille sceneområde, der fungerer som basarens offentlige mødested. Da byens rum bruges til at drøfte hverdagens glæder og problemer i de kulturer, som indvandrerne kommer fra, har Olav de Linde sikret sig, at basaren har en sådan funktion. Den virker som uformelt mødested, hvor man kan drøfte problemer og få viden. Og så kan man købe ind samtidig med. Den er en vigtig brik i, hvad man kunne kalde hjælp til selvhjælp.

"Ved at lægge basaren inde i Odense, så kan de beboere fra Vollsmose, som ønsker det, komme her ind og få en butik, og andre fra Vollsmose kan komme og købe sammen med andre Odense borgere. Så er man fri for den aversion, der er imod at tage til Vollsmose for at handle. Desuden så vi mulighederne i bygningerne her,” siger Olav de Linde (Marling, Kiib og Jensen, Experience City. DK 296). 
Arkitekt og planlægger Jette Nyrup fra Odense Kommune tilføjer: "Set fra vores side bliver Bazar Fyn betragtet som en mulighed for en kulturel kobling mellem Vollsmose og byens øvrige borgere ... Jeg synes, det er fedt, at det ligger her inde i byen, for det giver folkene fra Vollsmose et ærinde her inde i byen - men det giver også odenseborgerne et ærinde i et andet indkøbsmiljø. Det giver dem mulighed for at købe nogle ting, dufte nogle andre dufte, og det tror jeg, Odense har godt af ...” (297).

Bazar Fyn bryder med det traditionelle mønster, der typisk adskiller det offentliges og det private erhvervslivs rolle i integrationssammenhæng. Basaren sætter dermed spørgsmålstegn ved det utilstrækkelige i den hidtidige integrationspolitik, fordi social understøttelse og uddannelse ikke alene kan løse dette komplicerede spørgsmål.

Disse citerede udsagn understreger, at markedspladsen ikke blot opfattes som rammen om en "økonomisk rationalitet” - for handel og samhandel. Den er også ramme for interaktion mellem enkeltpersoner og grupper, og den er scene for "kulturelt møde og social udveksling” - mellem etniske danske og nydanske. Kulturbegrebet bruges her om hverdagskultur og som betegnelse for et samfundsmæssigt "kit". De seneste år har der været talt meget om "kultur i oplevelsesøkonomien" underforstået at "kultur" handler om "kunst", og samarbejdet mellem kultur og erhverv indbefatter kunstnernes anvendelse i en erhvervsmæssig sammenhæng og om erhvervslivets sponsorater til finkultur og sport. Bazar Fyn sætter spørgsmål ved denne "snævre" forståelse af dette samarbejde og bringer "verdenskulturen" til diskussion i en markedstænkning i forholdet I:I.

Bazar Fyn er blevet et "open-minded public domain". De 250 personer, der har deres daglige arbejdsplads i eller i tilknytning til basaren, og de 15.000 ugentligt besøgende vidner om stor kulturel mangfoldighed. Området er ydermere befolket af mange forskellige virksomheder, der bruger basarens butikker og "take away". Som helhed er der skabt et felt af nye energier - både erhvervsmæssigt og kulturelt.

\section{Performativ arkitektur på Frederiksberg nye bymidte}

Mens de to foregående eksempler har fokus på social interaktion via en bevidst strategi, der har det kulturelle indhold som omdrejningspunkt, så handler det tredje og sidste eksempel om arkitekturens rolle i "the Experience city", dvs. arkitekturen som formidler af læring og nye sanselige oplevelser. Eksemplet handler om Frederiksberg Nye Bymidte, der består af fem større og mindre koblende byrum med hver deres funktion og visuelle udtryk. Der er tale om en række forskellige transitrum, der byder på forunderlige sanseindtryk og uventede iscenesættelser af naturen i byen. Med en kombination af rumlige kvaliteter og sanselige virkninger af anvendte materialer og planter samt specielle effekter med lyd, lys, vand og damp annonceres en ny type af naturperformance midt i millionbyen.

Til grund for projektet ligger en del research, bl.a. er mobiliteten i området 
afdækket, de arkitektoniske og rumlige forhold analyseret og lokale programmer og ønsker inddraget.

Godt 30.000 forgængere og cyklister opholder sig eller krydser dagligt pladserne - nogle på gennemrejse fra Nørrebro til Valby andre på vej til eller fra metrostationen eller Frederiksberg Centret. En stor gruppe unge under uddannelse bruger pladserne som en del af deres studiemiljø.

Stig L. Andersson, der er arkitekten bag bymidteprojektet, har opfattet det som sin opgave at skabe byliv og at holde på nogle af de mange mennesker, der kommer forbi dagligt - at få dem ned i fart og skærpe deres opmærksomhed på stedet og på hinanden (Marling, Kiib og Jensen, Experience City. DK).

Ved hjælpe af blomster og træer skifter pladserne karakter og farver med årstiderne. Beplantningen er valgt og placeret med omhu, således at det er muligt at opleve vinden, når den kommer susende fra vest - men også sol og læ. Det danske regnvejr bliver iscenesat på elegant vis. Stig L. Andersson fortæller, at han er meget optaget af det danske klima og nuancerne gråt i gråt, som han finder, der designmæssigt er mange muligheder i. "Jeg synes at det er fantastisk, når det lige har regnet, og solen pludselig kommer frem. Der opstår et næsten silende lys, som kommer ned gennem den vandtætte himmel og spejler sig i alle de våde områder. Jeg har gerne villet lavet et byrum, der kan fange dette," fortæller han (197).

De designmæssige virkemidler på den største af de fem pladser, Solbjerg Plads, er små cirkler, der er fræset ned i flisebelægningen. De opsamler regndråberne og reflekterer solens stråler. To skyer af vanddampe ligger over pladsen. Når vinden kommer, bevæger de sig rundt. Et vandgardin er et tredje element.

Der arbejdes med lyd og lys på pladserne. Om natten effektbelyses træer, vandgardin, vanddampe mv. Pladserne performer på eventyrlig vis med en scenografi, der henter inspiration fra teaterverdenen. Også om aftenen kommer byens borgere og sætter sig for at nyde sceneriet eller lytte til pladsens forunderlige lyde, fortæller Frederiksbergs stadsgartner. Lydene kommer fra 32 lydbrønde, der udsender dæmpet musik eller dyre-lyde.

"Hele projektet, det handler om at sanse det sted, man er. At sanse sig selv. Om at opleve det her sted med sine egne sanser og at få sanserne stimuleret. Høre, lytte - høre løvfrøen, der hopper rundt fra den ene højtaler til den anden. Så er der jo ingen ende på, hvordan man kan associere til sin barndom, og alle mulige andre oplevelser, man har haft med frøer. De knytter sig alle i et eller andet omfang til naturen, og så bliver dette her til en naturoplevelse. Måske undrer man sig, fordi lyden og byens lugte ikke hænger sammen," siger Stig L. Andersson.

Han mener, at det er fantastisk, hvis man i det hele taget kan få nogen til at undre sig og reflektere. For det betyder, at de er på vej til at erhverve sig en ny erkendelse (197).

Byrummene i Frederiksberg nye bymidte performer. Ikke med reklametilbud, film eller tilsvarende underholdningstilbud produceret af andre for at fornøje. Rummene iscenesætter en bymæssig naturoplevelse, som er meget forskellig fra en 
naturoplevelse på landet, ved kysten. Arkitekten har ikke villet skabe en kopi - eller et guldaldermaleri - af en naturidyl. I stedet har det været målet at skabe drømme og sanseindtryk. Naturen bringes, som det fremgår ovenfor, ind i byen på en associativ vis.

Eksemplet vedrørende Frederiksberg Bymidte handler om sanselig arkitektur og åben stedslighed. Den introducerer en diskussion af arkitekturens rolle i oplevelsessamfundet, hvor brugerne selv indlejrer deres oplevelser, og hvor værket bliver til $\mathrm{i}$ en interaktion mellem rummet, de performative elementer og brugernes egne erindringer, erfaringer og følelser.

\section{Kulturel podning af byens arkitektur, rum og liv}

Undersøgelser viser, at bylivet, arkitekturen og byens rum i disse år påvirkes af oplevelsesøkonomiens fremmarch. I Danmark sker det overalt fra den mindste bykommune til hovedstaden. København har oplevet, hvad man kunne kalde en kulturel eksplosion i de seneste 15 - 20 år.

Udviklingen er et tveægget sværd. Den økonomiske tvang og de mange arrangementer sætter byen og bymiljøet under pres. De almindelige hverdagsrutiner besværliggøres, og visuelt opleves der ofte en forarmelse af bymiljøet. Byens arkitektur henvises desuden ofte til en rolle som kulisse for løjerne. Samtidig er vi imidlertid vidne til en række nye hybride kulturprojekter, designs og events, der vil andet og mere end at underholde. De åbner byen socialt og kulturelt og skaber sanselige oplevelser gennem kulturel podning af byen. Med kulturen som motor skabes et mangfoldigt byliv og en demokratisk åben by. Vi kalder denne by for "experience city", fordi den stiller krav om et hybridt sammensat kulturprogram af høj kvalitet; krav til læring og til fordybelse. Den giver anledning til undren og oplevelse, og den udvikler nye former for kulturelle mødesteder, rum og arkitektur. ${ }^{\text {. }}$

I Artiklen har trukket enkelte eksempler på hybride kulturprojekter frem. Empirien er hentet fra bogen Experience City. DK, der rummer mange og forskelligartede eksempler på sådanne projekter. Bogen er udar- bejdet sammen med mine kolleger, professor Hans Kiib og professor Ole B. Jensen. Den formidler resultater fra et igangværende forskningsprojekt ved Institut for Arkitektur \& Design, Aalborg Universitet. 


\section{LITTERATURHENVISNINGER}

Coates, Nigel. Ecstacity. London: Laurence King Publisher Ltd, 2003.

Haajer, Martin og Arnold Reijndorp. In Search of New Public Domains. Rotterdam: Nai Publisher, 2003.

"H.K.H. Prins Joachim indvier Bazar Fyn.” Odense Kommunes hjemmeside. Pressemeddelelser 2007, 26. september 2008. http://www.odense.dk/.

Marling, Gitte. "Designing the Experience City.” Journal for Architectural Research I (2008).

Marling, Gitte og Martin Zerlang, red. Fun City, København: Arkitektens Forlag, 2007.

Marling, Gitte og Helle Juul. “Byrum i Jylland.” Arkitekten, I, København: Arkitektens Forlag (2008).

Marling, Gitte, Hans Kiib og Ole B. Jensen. Experience City. DK. Aalborg: Aalborg Universitetsforlag, 2009.

Marling, Gitte, Ole. B. Jensen og Hans Kiib. “The Experience City: Planning of Hybrid Cultural Projects.” European Planning Studies, I7, 6, juni (2009): 863-885.

Metz, Tracy. Fun, Leisure and Landscape. Rotterdam: Nai Publisher, 2002.

Pine, B.J. og J.H. Gilmore. The Experience Economy. Work is Theater and Every Business is a Stage. Boston: Harvard Business School Press, I999.

Sorkin, Michael, red. Varation on a Theme Park - the New American City and the End of Public Places, New Yorh: Hill \& Wang, I992.

Waltzer, M. "Pleasure and Cost of urbanity." Introduction to Metropolis - Center and Symbol of our Times, red. P. Kasinitz. New York: New York University Press, 1995. 320-336. 